\title{
Inhibition of rennet activity in cheese using equine blood serum
}

\author{
Nidhi BansaL ${ }^{*}$, Patrick F. Fox, Paul L. H. McSweeney \\ Department of Food and Nutritional Sciences, University College, Cork, Ireland \\ Received 1st May 2009 - Revised 12 May 2010 - Accepted 17 May 2010 \\ Published online 8 July 2010
}

\begin{abstract}
The objective of this study was to inactivate chymosin in Cheddar-type cheese curd using equine blood serum. This blood serum was added $(0.1-2 \%, \mathrm{v} / \mathrm{v})$ to cheesemilk at $15{ }^{\circ} \mathrm{C}$ after completion of the first phase of renneting and before aggregation of the rennet-altered casein micelles, to inhibit the residual coagulant in Cheddar-type cheeses. Throughout ripening the level of $\mathrm{pH}$ 4.6-soluble nitrogen expressed as a percentage of total nitrogen was significantly higher in the control cheeses than in experimental cheeses and was about twice that of the experimental cheeses after ripening for 180 days. During ripening, there was almost no hydrolysis of $\alpha_{\mathrm{s} 1}$-casein in the cheeses made from milk containing $0.25-2 \%$ blood serum. Throughout ripening there were large quantitative differences between the peptide profiles of control and experimental cheeses. The results of this study suggest that the addition of equine blood serum to cheesemilk $(0.25-2 \%)$ was very effective at inhibiting the residual chymosin activity in Cheddar-type cheeses during ripening; the activity of plasmin remained unaffected by the added blood serum. This study describes an easy and effective method for producing cheese curd free from residual coagulant activity, which will help to study the separate roles of the coagulant and other proteolytic enzymes in cheese ripening.
\end{abstract}

equine blood serum / Cheddar cheese / chymosin / milk coagulation

\begin{abstract}
摘要 - 马血清对干酪中凝乳酶活性的抑制作用。研究了利用马血清对类契达干酪凝块中凝 乳酶活性的抑制作用。在凝乳的最初相形成后和酪蛋白胶束酶凝聚之前, 在 $15{ }^{\circ} \mathrm{C}$ 下将马 血清 $(0.1 \sim 2 \%, \mathrm{v} / \mathrm{v})$ 加到干酪用乳中以抑制类契达干酪凝块中残余凝乳剂的活性。在整个 成熟阶段，对照组干酪的 pH 4.6 可溶性氮占总氮的百分率 (SN/TN) 显著地高于实验组，而 且成熟 $180 \mathrm{~d}$ 后, 对照组 SN/TN 值约是实验组的 2 倍。在成熟期间, 含有 $0.25 \% \sim 2 \%$ 马 血清的干酪中几乎没有 $\alpha_{\mathrm{s} 1}$-酪蛋白的水解。在整个成熟过程中, 对照组和实验组肽的特 性完全不同。研究结果表明, 在干酪用乳中添加马血清可以有效地抑制类契达干酪中残 余凝乳酶的活性，而且马血清对血纤维蛋白溶酶的活性没有影响。本文介绍了一种有 效地抑制干酪凝块残余凝乳剂的方法, 该法将有助于研究在干酪成熟过程中凝乳剂及其 他蛋白水解酶的作用。
\end{abstract}

\section{马血清 / 契达干酪 / 凝乳酶 / 乳的凝固}

Résumé - Inhibition de l'activité de la présure dans les fromages par le sérum sanguin de cheval. L'objectif de cette étude était d'inactiver la chymosine dans le caillé de fromage de type Cheddar par du sérum sanguin de cheval. Du sérum sanguin de cheval a été ajouté $(0,1$ à $2 \% \mathrm{v} / \mathrm{v})$ au lait destiné à la fabrication du fromage à une température de $15^{\circ} \mathrm{C}$ après la prise et avant l'agrégation des micelles de caséine modifiées par la présure, afin d'inhiber l'agent coagulant

*Corresponding author (通讯作者): n.bansal@uq.edu.au 
résiduel dans les fromages de type Cheddar. Tout au long de l'affinage, le niveau d'azote soluble à $\mathrm{pH}$ 4,6 sur l'azote total (SN/TN) était significativement plus élevé dans les fromages témoins et était environ deux fois plus élevé que celui des fromages expérimentaux après 180 jours. Durant l'affinage, il n'y avait pratiquement aucune hydrolyse de la caséine $\alpha_{\mathrm{s} 1}$ dans les fromages fabriqués à partir de lait contenant de 0,25 à $2 \%$ de sérum sanguin. Au cours de l'affinage, de grandes différences quantitatives étaient observées entre les profils peptidiques des fromages témoins et expérimentaux. Les résultats de cette étude suggèrent que l'addition de sérum sanguin de cheval au lait de fromagerie $(0,25-2 \%)$ se montrait un moyen efficace pour inhiber l'activité de la chymosine résiduelle dans les fromages de type Cheddar au cours de l'affinage ; l'activité de la plasmine restait inchangée. Cette étude décrit une méthode simple et efficace pour produire des caillés de fromage sans activité coagulante résiduelle, qui permettra d'étudier les rôles réciproques du coagulant et des autres enzymes protéolytiques au cours de l'affinage du fromage.

sérum sanguin équin / fromage Cheddar / chymosine / coagulation du lait

\section{INTRODUCTION}

Rennet is the generic term for any enzyme preparation used to coagulate milk during cheesemaking. The principal role of the rennet is to coagulate milk, but it also contributes to proteolysis during the ripening of most cheeses, particularly in low/ medium-cooked varieties [10, 21, 29, 34]. Proteolysis is perhaps the most complex biochemical event in cheese during ripening and involves proteolytic enzymes from four, and in some varieties five, sources: (1) rennet or rennet substitute; (2) indigenous milk proteinases; (3) enzymes from starter bacteria, which are released after the cells have lysed; (4) proteinases and peptidases from non-starter bacteria; and (5) enzymes from secondary cultures. Studies on cheese with a controlled microflora have shown that the residual coagulant is responsible for the level of proteolysis detected by gel electrophoresis and for most of the nitrogen soluble in water or at $\mathrm{pH} 4.6[21,36,37]$. The residual rennet is partially responsible for the softening of cheese during ripening $[6,7]$. Proteolysis by residual rennet also influences the flavour of cheese. Some peptides produced by rennet are small enough to influence flavour directly but mainly because the chymosin-produced peptides are further hydrolysed by microbial proteinases and peptidases to small peptides and amino acids which contribute at least to the background flavour and, perhaps, to bitterness if the activity of such enzymes is excessive. Catabolism of amino acids by microbial enzymes, and perhaps alterations via chemical mechanisms, leads to a range of sapid compounds that are major contributors to characteristic cheese flavours [11].

To study the separate roles of the coagulant and other proteolytic enzymes in cheese ripening, various techniques have been used to make "rennet-free" cheeses. Visser [35] described a complicated technique for the manufacture of "rennet-free" cheese by depleting cheesemilk of $\mathrm{Ca}^{2+}$, thus permitting the first phase of renneting to be completed without coagulation. Some researchers used porcine pepsin as a coagulant and inactivated it by raising the $\mathrm{pH}$ of the curds-whey mixture to $7.0[16,20]$; others used piglet gastric proteinase as a coagulant [19]. Shakeel-Ur-Rehman et al. [27] used an inhibitor specific for aspartyl proteinases, pepstatin A, to inhibit the activity of coagulant and prepare "rennet-free" cheeses. There have been several reports on the "anti-rennet" properties of blood serum from various species $[2,3,13,24$, $25,26,28,33]$. The ability of blood serum to inactivate enzymes in rennet seems to be very promising for making "rennet-free" cheeses, but no such cheese has been made to date. Studies have shown that among 
the blood serum of various species that from horse is most potent in inhibiting chymosin $[3,13,26,33]$. Hence, equine blood serum was used in this study.

The objective of this study was to inactivate chymosin in Cheddar-type cheese curd by adding equine blood serum to cheesemilk after the completion of first phase of renneting and before the aggregation of rennet-altered casein micelles.

\section{MATERIALS AND METHODS}

\subsection{Cheese manufacture}

Whole milk (3.6\% fat and 3.2\% protein) was standardised to casein:fat ratio of $0.7: 1$, pasteurised at $63{ }^{\circ} \mathrm{C}$ for $30 \mathrm{~min}$ and cooled to $15^{\circ} \mathrm{C}$ for cheesemaking. Cheddar-type cheeses were manufactured from $1.5 \mathrm{~L}$ portions of milk. A direct-vat-set starter culture (R604, Christian Hansen, Hoersholm, Denmark) and $1 \mathrm{~mol} \cdot \mathrm{L}^{-1} \mathrm{CaCl}_{2}$ were added to the cheesemilk at $15{ }^{\circ} \mathrm{C}$ at a level of $0.02 \%(\mathrm{w} / \mathrm{v})$ and $0.07 \%(\mathrm{v} / \mathrm{v})$, respectively. After ripening the cheesemilk for $15 \mathrm{~min}$, fermentation-produced calf chymosin (Chy-Max, 180 IMCU.mL ${ }^{-1}$; Christian Hansen) was added at a level of $0.02 \%$ $(\mathrm{v} / \mathrm{v})$ at $15^{\circ} \mathrm{C}$. The first phase of renneting at $15{ }^{\circ} \mathrm{C}$ was complete $1 \mathrm{~h}$ after rennet addition as described by Bansal [3]. Equine blood serum (Sigma Chemical Co., St. Louis, MO, USA) was then added to the renneted milk at a level of 0 (control), $0.4 \%, 1 \%$ and $2 \%(\mathrm{v} / \mathrm{v})$ to inhibit the chymosin. Results of a previous study [3] showed that the inhibition of chymosin by blood requires about $1 \mathrm{~h}$ for completion; therefore, the renneted cheesemilk was held at $15{ }^{\circ} \mathrm{C}$ for $1 \mathrm{~h}$ after the addition of equine blood serum. The milk was then warmed slowly in a water bath to $30{ }^{\circ} \mathrm{C}$ to induce coagulation. The coagulum was cut and cheeses manufactured according to a standard protocol [9]. The whey was drained off at $\mathrm{pH} 6.2$ and the curds cheddared, milled at $\mathrm{pH} 5.2$ and salted at a level of $2.5 \%(\mathrm{w} / \mathrm{w})$. After pressing the curds at $32 \mathrm{kPa}$ for $18 \mathrm{~h}$, the cheeses were vacuum-packed and ripened at $8{ }^{\circ} \mathrm{C}$ for 180 days. Samples were taken from the centre and near the edge of each cheese and mixed homogeneously as one sample after 1, 42, 90 and 180 days of ripening and stored at $-20{ }^{\circ} \mathrm{C}$ until analysed. All the cheeses were manufactured in triplicate. Based on the results of Trials A and B, the levels of blood serum added to cheesemilk were modified to $0 \%, 0.1 \%, 0.25 \%, 0.4 \%$ and $2 \%(\mathrm{v} / \mathrm{v})$ for Trial $\mathrm{C}$.

\subsection{Analysis of composition and proteolysis}

The composition $(\mathrm{pH}$, moisture, protein and salt) of 42 day-old cheeses from all the three trials was determined in triplicate as described by O'Mahony et al. [23].

Proteolysis in the cheeses was assessed by urea-polyacrylamide gel electrophoresis (urea-PAGE) (12.5\% total acrylamide, 4\% cross-linking agent, and $\mathrm{pH}$ 8.9) according to the method described by Bansal et al. [4]. The $\mathrm{pH} 4$ 4-6-soluble and -insoluble fractions of the cheeses were prepared according to the method of Kuchroo and Fox [15], as modified slightly by Sousa and McSweeney [30]. The $\mathrm{N}$ content of the $\mathrm{pH}$ 4.6-soluble fraction of the cheeses was measured by the macro-Kjeldahl method [14] and expressed as a percentage of the total $\mathrm{N}$ content of the cheeses. The $\mathrm{pH}$ 4.6-soluble fractions of the cheeses were analysed by reverse-phase high-performance liquid chromatography (RP-HPLC) according to the method of Sousa and McSweeney [30].

\subsection{Statistical analysis}

Analysis of variance (one-way ANOVA) on data for the composition and levels of $\mathrm{pH}$ 4.6-soluble $\mathrm{N}$ of the cheeses was performed using the statistical analysis 
software SPSS v 13.0 for Windows XP (SPSS Inc., Chicago, USA). Results presented are the mean of triplicate analyses. Data from RP-HPLC chromatograms of the $\mathrm{pH}$ 4.6-soluble fractions of the cheeses were analysed using multivariate statistical techniques. The peak height data were pre-processed according to the method of Piraino et al. [25]. The output from this pre-processing consisted of retention time classes within which peak heights were accumulated using the distance from centre of class as a weight. Principal component (PC) analysis and hierarchical cluster analysis were then performed on the pre-processed data using a covariance matrix and the between-group linkage cluster method, respectively, using SPSS.

\section{RESULTS AND DISCUSSION}

\subsection{Cheese composition}

Within a trial, there were no significant differences $(P>0.05)$ in the protein content and $\mathrm{pH}$ between the 42 day-old cheeses (Tab. I); the moisture and salt content of the cheeses varied slightly both with the level of blood serum added and between trials. In Trials $\mathrm{A}$ and $\mathrm{B}$, the moisture content and the salt-in-moisture content of the cheeses made from milk containing $2 \%$ serum were the lowest among all cheeses (Tab. I).

\section{2. pH 4.6-soluble nitrogen}

The level of $\mathrm{pH}$ 4.6-soluble nitrogen as a percentage of total nitrogen $(\mathrm{pH}$ 4.6-SN/ $\mathrm{TN})$ in Cheddar cheeses varied significantly $(P \leq 0.05)$ with the level of blood serum added to cheesemilk and with ripening time (Tab. II); there were significant differences $(P \leq 0.05)$ in the level of $\mathrm{pH} 4.6-\mathrm{SN} / \mathrm{TN}$ in cheeses between the trials and hence, the data for the three trials are presented. At both ripening times, the level of $\mathrm{pH}$ 4.6-SN/TN was significantly higher in the control cheeses than in the experimental cheeses (Tab. II) and the level of pH 4.6$\mathrm{SN} / \mathrm{TN}$ increased significantly in all cheeses as ripening progressed. Between 1 and 180 days of ripening, the level of $\mathrm{pH}$ 4.6$\mathrm{SN} / \mathrm{TN}$ increased from $\sim 4$ to $\sim 18 \%$ in the control and from $\sim 3$ to $\sim 9 \%$ in the experimental cheeses.

Coagulant activity is inhibited by equine blood serum [2, 3, 8, 13, 33]. Since the coagulant is mainly responsible for the formation of $\mathrm{pH} 4$ 4-6-soluble nitrogen $[21,36]$, the lower level of primary proteolysis in the experimental cheeses suggests that the activity of chymosin was inhibited in those cheeses. The results for the control cheese are in general agreement with previous reports of Cheddar cheese [9, 16, 22]. The difference in the level of $\mathrm{pH}$ 4.6-SN/TN between the 180-day-old control and the experimental cheeses $(\sim 9 \%)$ was similar to that reported for "rennet-free" Cheddartype cheeses prepared using pepstatin A [27]. Visser [36] reported a difference of $\sim 4 \%$ in the level of water-soluble nitrogen (WSN) between 3-month-old "rennet-free" Gouda cheeses and control, and Lane et al. [16] reported $\sim 6 \%$ difference in the WSN between a 4-month-old "rennet-free" Cheddar cheese and control. The level of primary proteolysis in cheeses made from milk containing $0.25 \%, 0.4 \%$ or $2 \%$ blood serum was similar both at 1 and 180 days of ripening. These results suggest that equine blood serum inhibits proteolysis by chymosin in cheese at a level as low as $0.25 \%$ (v/v milk).

\subsection{Urea-PAGE}

Similar electrophoretic results were obtained for the three trials; the results for Trial $\mathrm{C}$ are presented. $\beta$-Casein was hydrolysed slightly by chymosin to produce $\beta-C N$ (f1-189/192) during ripening of the control and, to a lesser extent, in cheeses made from milk containing $0.1 \%$ serum. Due to the inhibition of chymosin by blood 
Table I. Composition and $\mathrm{pH}$ of 42 -day-old Cheddar cheeses made from milk containing $0 \%$ (control), $0.1 \%, 0.25 \%, 0.4 \%, 1 \%$ or $2 \%(\mathrm{v} / \mathrm{v})$ equine blood serum.

\begin{tabular}{|c|c|c|c|c|}
\hline \multirow[t]{2}{*}{ Parameter } & \multirow{2}{*}{$\begin{array}{l}\text { Level of equine blood } \\
\text { serum }(\%, v / v \text {, of milk) }\end{array}$} & \multicolumn{3}{|c|}{ Trial } \\
\hline & & $\mathrm{A}$ & $\mathrm{B}$ & $\mathrm{C}$ \\
\hline \multirow[t]{6}{*}{ Moisture (\%) } & Control & $34.5 \pm 0.18^{\mathrm{a}}$ & $35.1 \pm 0.15^{\mathrm{a}, \mathrm{b}}$ & $35.9 \pm 0.23^{\mathrm{a}}$ \\
\hline & 0.1 & - & - & $35.4 \pm 0.27^{\mathrm{a}}$ \\
\hline & 0.25 & - & - & $35.8 \pm 0.22^{\mathrm{a}}$ \\
\hline & 0.4 & $34.7 \pm 0.07^{\mathrm{a}}$ & $34.8 \pm 0.24^{\mathrm{b}}$ & $36.7 \pm 0.22^{\mathrm{b}}$ \\
\hline & 1 & $34.2 \pm 0.14^{\mathrm{b}}$ & $35.3 \pm 0.15^{\mathrm{a}}$ & - \\
\hline & 2 & $33.7 \pm 0.11^{\mathrm{c}}$ & $34.1 \pm 0.13^{\mathrm{c}}$ & $37.1 \pm 0.21^{\mathrm{b}}$ \\
\hline \multirow[t]{6}{*}{ Protein (\%) } & Control & $27.7 \pm 0.31^{\mathrm{a}}$ & $27.2 \pm 0.48^{\mathrm{a}}$ & $27.7 \pm 0.27^{\mathrm{a}}$ \\
\hline & 0.1 & - & - & $27.8 \pm 0.79^{\mathrm{a}}$ \\
\hline & 0.25 & - & - & $27.7 \pm 0.31^{\mathrm{a}}$ \\
\hline & 0.4 & $27.6 \pm 0.14^{\mathrm{a}}$ & $27.1 \pm 0.41^{\mathrm{a}}$ & $28.4 \pm 0.65^{\mathrm{a}}$ \\
\hline & 1 & $27.4 \pm 0.21^{\mathrm{a}}$ & $26.5 \pm 0.14^{\mathrm{a}}$ & - \\
\hline & 2 & $27.2 \pm 0.29^{\mathrm{a}}$ & $27.3 \pm 0.84^{\mathrm{a}}$ & $27.3 \pm 0.59^{\mathrm{a}}$ \\
\hline \multirow[t]{6}{*}{ Salt (\%) } & Control & $1.5 \pm 0.02^{\mathrm{a}}$ & $1.4 \pm 0.02^{\mathrm{a}}$ & $1.6 \pm 0.01^{\mathrm{a}}$ \\
\hline & 0.1 & - & - & $1.6 \pm 0.07^{\mathrm{a}, \mathrm{b}}$ \\
\hline & 0.25 & - & - & $1.6 \pm 0.01^{\mathrm{a}}$ \\
\hline & 0.4 & $1.3 \pm 0.01^{\mathrm{b}}$ & $1.5 \pm 0.02^{\mathrm{a}, \mathrm{b}}$ & $1.7 \pm 0.06^{\mathrm{b}}$ \\
\hline & 1 & $1.4 \pm 0.04^{\mathrm{a}}$ & $1.6 \pm 0.04^{\mathrm{b}}$ & - \\
\hline & 2 & $1.5 \pm 0.02^{\mathrm{a}}$ & $1.7 \pm 0.06^{\mathrm{c}}$ & $1.6 \pm 0.10^{\mathrm{a}, \mathrm{b}}$ \\
\hline \multirow[t]{6}{*}{$\mathrm{pH}$} & Control & $5.1 \pm 0.02^{\mathrm{a}}$ & $5.1 \pm 0.01^{\mathrm{a}, \mathrm{b}}$ & $5.2 \pm 0.04^{\mathrm{a}}$ \\
\hline & 0.1 & - & - & $5.2 \pm 0.03^{\mathrm{a}}$ \\
\hline & 0.25 & - & - & $5.1 \pm 0.03^{\mathrm{a}}$ \\
\hline & 0.4 & $5.1 \pm 0.02^{\mathrm{a}}$ & $5.1 \pm 0.01^{\mathrm{a}}$ & $5.2 \pm 0.01^{\mathrm{a}}$ \\
\hline & 1 & $5.1 \pm 0.01^{\mathrm{a}}$ & $5.1 \pm 0.02^{\mathrm{a}}$ & - \\
\hline & 2 & $5.1 \pm 0.01^{\mathrm{a}}$ & $5.2 \pm 0.02^{\mathrm{b}}$ & $5.2 \pm 0.02^{\mathrm{a}}$ \\
\hline \multirow[t]{6}{*}{$\mathrm{S} / \mathrm{M}^{1}$} & Control & $4.2 \pm 0.05^{\mathrm{a}, \mathrm{b}}$ & $4.1 \pm 0.07^{\mathrm{a}}$ & $4.3 \pm 0.02^{\mathrm{a}}$ \\
\hline & 0.1 & - & - & $4.6 \pm 0.21^{\mathrm{a}}$ \\
\hline & 0.25 & - & - & $4.4 \pm 0.05^{\mathrm{a}}$ \\
\hline & 0.4 & $3.7 \pm 0.04^{\mathrm{c}}$ & $4.4 \pm 0.07^{\mathrm{b}}$ & $4.7 \pm 0.14^{\mathrm{a}}$ \\
\hline & 1 & $4.1 \pm 0.11^{\mathrm{b}}$ & $4.4 \pm 0.09^{b}$ & - \\
\hline & 2 & $4.4 \pm 0.04^{\mathrm{a}}$ & $5.1 \pm 0.17^{\mathrm{c}}$ & $4.4 \pm 0.25^{\mathrm{a}}$ \\
\hline
\end{tabular}

${ }^{1} \mathrm{~S} / \mathrm{M}$, salt in moisture.

Numbers represent means and standard deviations $(n=3)$; means within a column with different superscripts were significantly different (Tukey's HSD, $P<0.05$ ).

serum, the $\beta-\mathrm{CN}$ (f1-189/192) was not produced in cheeses made from milk containing $0.25-2 \%$ blood serum. In both control and experimental cheeses, $\beta$-casein was also hydrolysed by plasmin to $\beta-\mathrm{CN}$ (f29-209), $\beta-\mathrm{CN}$ (f106-209) and $\beta-\mathrm{CN}$ (f108-209), i.e. $\gamma_{1^{-}}, \gamma_{2^{-}}$and $\gamma_{3^{-}}$-caseins, respectively (Fig. 1). The activity of plasmin in milk incubated at $37^{\circ} \mathrm{C}$ for 7 days and in plasmin solution is inhibited in the presence of blood serum [13, 31]. However, the results of this study suggest that the activity of plasmin remained unaffected in cheese made with milk containing blood serum.

The activity of plasmin might have been unaffected in cheese because 
Table II. Levels of $\mathrm{pH}$ 4.6-soluble nitrogen (expressed as a percentage of total nitrogen) in Cheddar cheeses made from milk containing $0 \%$ (control), $0.1 \%, 0.25 \%, 0.4 \%, 1 \%$ or $2 \%(\mathrm{v} / \mathrm{v})$ equine blood serum after 1 and 180 days of ripening.

\begin{tabular}{|c|c|c|c|c|}
\hline \multirow{2}{*}{$\begin{array}{l}\text { Ripening time } \\
\text { (days) }\end{array}$} & \multirow{2}{*}{$\begin{array}{c}\text { Level of equine blood } \\
\text { serum }(\%, v / v \text {, of milk) }\end{array}$} & \multicolumn{3}{|c|}{ Trial } \\
\hline & & A & B & $\mathrm{C}$ \\
\hline \multirow[t]{6}{*}{1} & Control & $4.4 \pm 0.45^{\mathrm{a}}$ & $3.99 \pm 0.04^{\mathrm{a}}$ & $3.49 \pm 0.06^{\mathrm{a}}$ \\
\hline & 0.1 & - & - & $2.82 \pm 0.11^{\mathrm{b}}$ \\
\hline & 0.25 & - & - & $2.79 \pm 0.04^{\mathrm{b}}$ \\
\hline & 0.4 & $3.14 \pm 0.11^{\mathrm{b}}$ & $3.23 \pm 0.08^{\mathrm{b}}$ & $2.73 \pm 0.06^{\mathrm{b}}$ \\
\hline & 1 & $3.39 \pm 0.42^{\mathrm{b}}$ & $2.94 \pm 0.02^{\mathrm{c}}$ & - \\
\hline & 2 & $3.39 \pm 0.20^{\mathrm{b}}$ & $2.74 \pm 0.12^{\mathrm{d}}$ & $2.75 \pm 0.05^{\mathrm{b}}$ \\
\hline \multirow[t]{6}{*}{180} & Control & $16.98 \pm 0.77^{\mathrm{a}}$ & $17.65 \pm 0.46^{\mathrm{a}}$ & $18.12 \pm 0.24^{\mathrm{a}}$ \\
\hline & 0.1 & - & - & $13.43 \pm 0.61^{b}$ \\
\hline & 0.25 & - & - & $9.36 \pm 0.13^{\mathrm{c}}$ \\
\hline & 0.4 & $8.84 \pm 0.09^{b}$ & $9.41 \pm 0.17^{\mathrm{b}}$ & $9.32 \pm 0.19^{c}$ \\
\hline & 1 & $8.63 \pm 0.35^{\mathrm{b}}$ & $10.03 \pm 0.21^{\mathrm{b}}$ & - \\
\hline & 2 & $7.16 \pm 0.21^{\mathrm{c}}$ & $10.12 \pm 0.29^{b}$ & $9.33 \pm 0.12^{\mathrm{c}}$ \\
\hline
\end{tabular}

Numbers represent means and standard deviations $(n=6)$; means within a column with different superscripts were significantly different (Tukey's HSD, $P<0.05$ ).

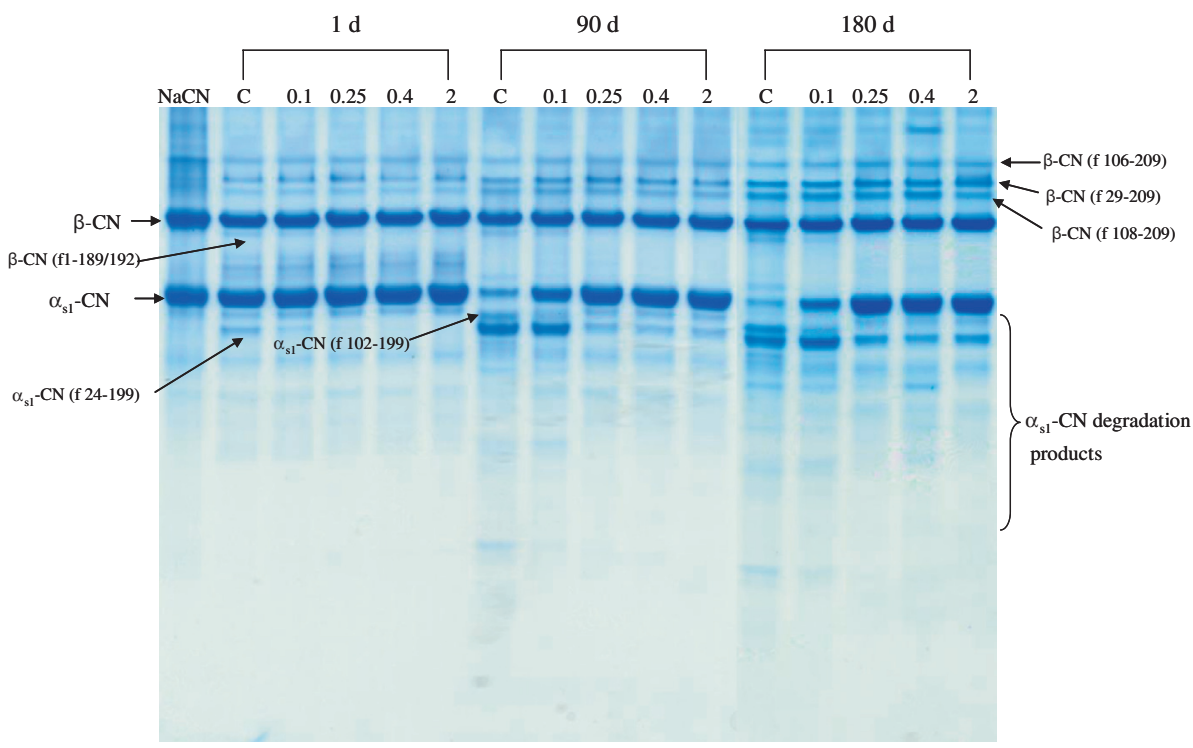

Figure 1. Urea-polyacrylamide gel electrophoretograms $(12.5 \% \mathrm{~T}, 4 \% \mathrm{C}$, and $\mathrm{pH} 8.9)$ of bovine sodium caseinate $(\mathrm{CN})$ and Cheddar cheeses manufactured from milk containing $0 \%$ (control), $0.1 \%, 0.25 \%, 0.4 \%$ or $2 \%$ equine blood serum after 1,90 , and 180 days of ripening. 


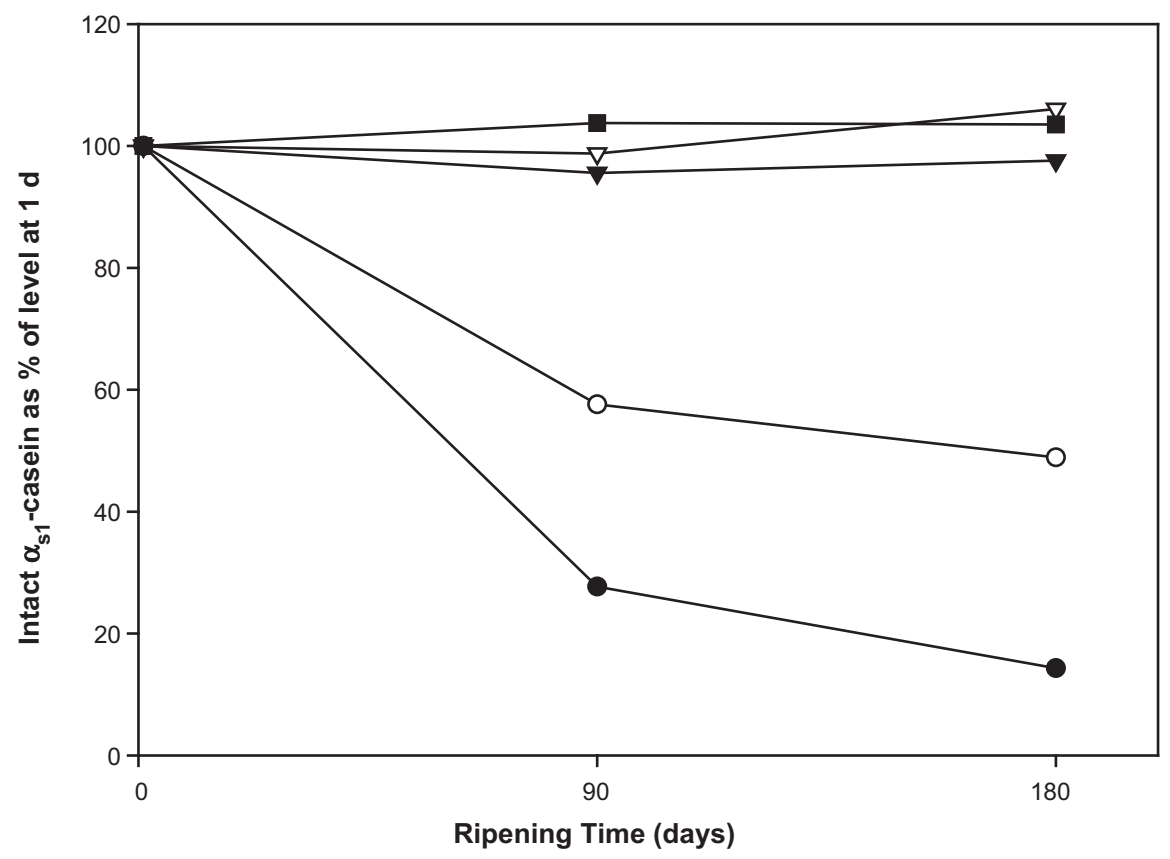

Figure 2. Level of intact $\alpha_{\mathrm{s} 1}$-casein as a percentage of the level at 1 day for Cheddar cheeses made from milk containing $0 \%(\bullet), 0.1 \%(\circ), 0.25 \%(\nabla), 0.4 \%(\nabla)$ or $2 \%(\boldsymbol{\bullet})$ equine blood serum after 1 , 90 , and 180 days of ripening.

(1) $\alpha_{2}$-macroglobulin $\left(\alpha_{2}-\mathrm{M}\right)$, which is presumably the principal "rennet-inhibitor" in blood serum $[1-3,13,17,32]$, has a unique mechanism of proteinase inhibition: the proteinase binds to the inhibitor and cleaves a specific peptide bond in the "bait" region of the $\alpha_{2}-\mathrm{M}$ molecule, inducing a conformational change in the $\alpha_{2}-\mathrm{M}$. As a result the proteinase molecule is entrapped and inhibited irreversibly within the modified $\alpha_{2}$-M molecule [5]. When blood serum was added to the cheesemilk, the level of chymosin in milk was higher than that of plasmin and hence, $\alpha_{2}$-M might have preferentially inhibited chymosin and become unavailable to inhibit plasmin; (2) plasmin in milk is associated with the casein micelles [39] and may be unable to interact with $\alpha_{2}-\mathrm{M}$ which would otherwise lead to its inhibition; or (3) during ripening, the $\alpha_{2}$-M molecules would be unable to inhibit the proteinases due to very restricted mobility in the cheese matrix structure.

$\alpha_{\mathrm{s} 1}$-Casein was hydrolysed extensively in the control and cheeses made from milk containing $0.1 \%$ blood serum, but there were significant differences between them in the rate of hydrolysis of $\alpha_{\mathrm{s} 1}$-casein during cheese ripening (Fig. 1). There was little hydrolysis of $\alpha_{\mathrm{s} 1}$-casein during ripening of the cheeses made from milk containing $0.25-2 \%$ blood serum; almost $100 \%$ of the $\alpha_{\mathrm{s} 1}$-casein was intact even after 180 days of ripening (Fig. 2). The level of intact $\alpha_{\mathrm{s} 1}$-casein in control and cheeses made from milk containing $0.1 \%$ blood serum after 180 days of ripening was about $14 \%$ and $50 \%$, respectively (Fig. 2). The primary site 

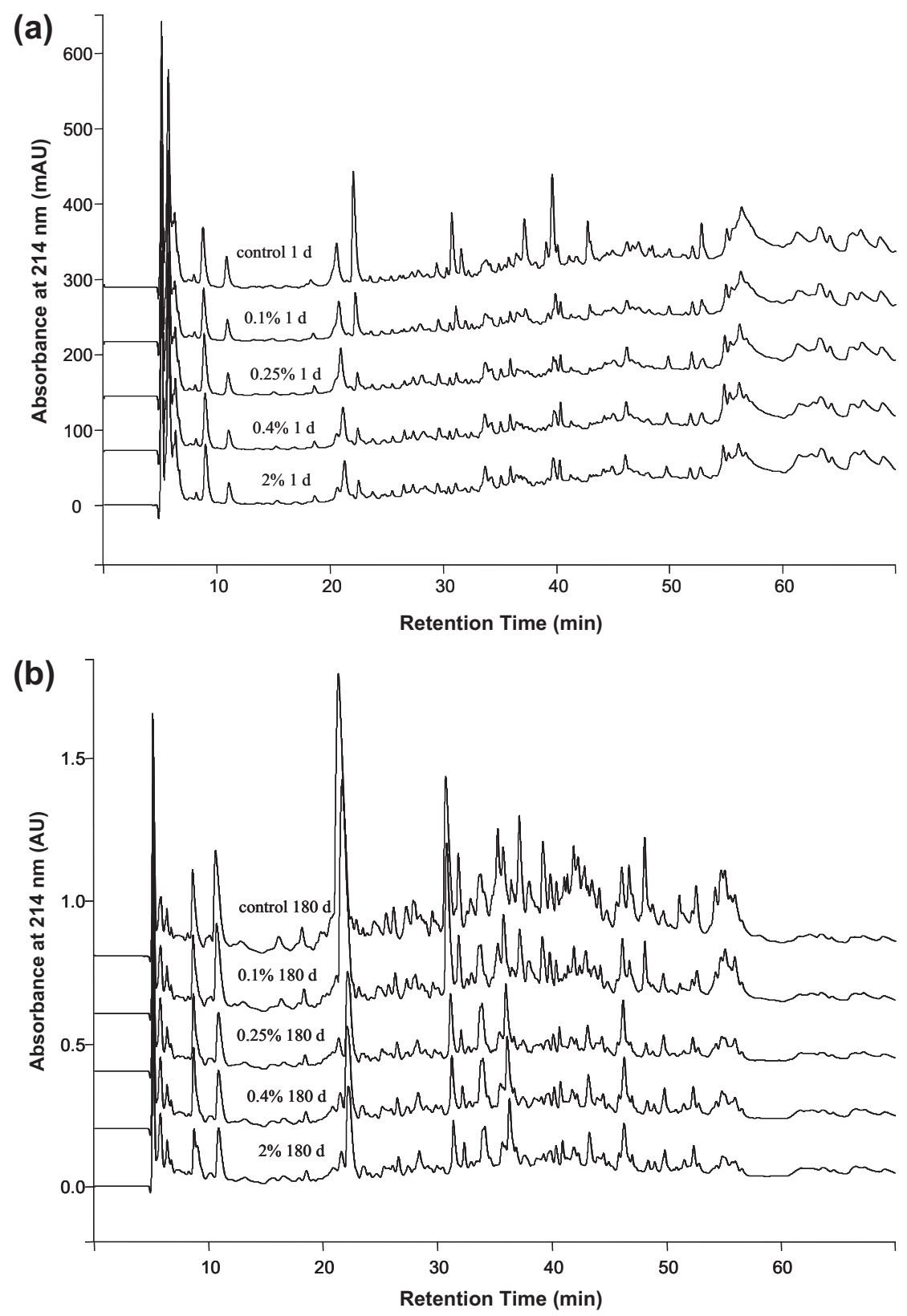

Figure 3. Reverse-phase HPLC chromatograms of the $\mathrm{pH}$ 4.6-soluble fractions of Cheddar cheeses made from milk containing $0 \%$ (control), $0.1 \%, 0.25 \%, 0.4 \%$ or $2 \%$ equine blood serum after 1 (a) and 180 (b) days of ripening. Different chromatograms are shown above each other on the same retention time axis. 
of chymosin action on $\alpha_{\mathrm{s} 1}$-casein is $\mathrm{Phe}_{23^{-}}$ $\mathrm{Phe}_{24}[12,18]$ hydrolysis of which produces $\alpha_{\mathrm{s} 1}-\mathrm{CN}$ (f24-199) and $\alpha_{\mathrm{s} 1}-\mathrm{CN}$ (f1-23). Little $\alpha_{\mathrm{s} 1}-\mathrm{CN}$ (f24-199) was produced in the experimental cheeses compared to control or cheese made from milk containing $0.1 \%$ blood serum after 90 days of ripening (Fig. 1). In the control cheese, $\alpha_{\mathrm{s} 1}-\mathrm{CN}$ (f24-199) was further cleaved by the coagulant, initially at $\mathrm{Leu}_{101}$-Lys 102 , producing the peptide $\alpha_{\mathrm{s} 1}-\mathrm{CN}$ (f102-199) from 90 days ripening onwards (Fig. 1). In all experimental cheeses, $\alpha_{\mathrm{s} 1}-\mathrm{CN}$ (f24-199) was not hydrolysed further due to the inhibition of chymosin (Fig. 1). The short peptide $\alpha_{\mathrm{s} 1}-\mathrm{CN}$ (f1-23) is hydrolysed rapidly by proteinases of starter microorganisms during ripening [38]. The similarity between the extent of hydrolysis of $\alpha_{\mathrm{s} 1}$-casein in cheeses made from milk containing $0.25 \%, 0.4 \%$ or $2 \%$ blood serum suggests that equine blood serum effectively inhibits proteolysis by chymosin in cheese at a level of $0.25 \%(\mathrm{v} / \mathrm{v})$.

\subsection{RP-HPLC peptide profiles}

Similar results were obtained for the three trials and the RP-HPLC peptide profiles of the $\mathrm{pH}$ 4.6-soluble fractions of Cheddar cheeses for Trial $\mathrm{C}$ are shown in Figures $3 \mathrm{a}$ and $3 \mathrm{~b}$. As ripening progressed, there were large quantitative differences between the peptide profiles of the control and experimental cheeses. Although the peptides produced in the experimental cheeses had retention times similar to those produced in control, and hence may be the same peptides, the quantity of peptides produced was much lower than in control. These quantitative differences in the peptide profiles of cheeses were very apparent after 180 days of ripening (Fig. 3b). These results are in agreement with the observation that the level of $\mathrm{pH}$ 4.6-SN/ $\mathrm{TN}$ in the control was higher than in the experimental cheeses throughout ripening (Tab. II). Lane et al. [16] and Shakeel-UrRehman et al. [27] also reported quantitative differences between the peptide profiles of control and "rennet-free" cheeses.

Peptides in the $\mathrm{pH}$ 4.6-soluble fractions reflect the action of the starter and, possibly, NSLAB proteinases and peptidases [11]. These quantitative differences in the peptide profiles of cheeses may arise because there was less primary proteolysis in the experimental than in the control cheeses due to the inhibition of chymosin and perhaps other proteinases by blood serum. Hence, the intermediate-sized peptides resulting from chymosin action were produced at much lower concentrations in experimental cheeses and were unavailable to starter proteinases and peptidases for the production of small peptides. It is less likely that the quantitative differences in the peptide profiles of cheeses were due to the effect of blood serum on the growth of the starter and NSLAB by inhibiting their proteinases and peptidases. Also, results of a separate study [3] suggested that the addition of equine blood serum to milk at levels up to $2 \%$ did not affect the growth of the cheese starter culture Lactococcus lactis UC317 in milk at $30{ }^{\circ} \mathrm{C}$. There was no significant difference in the $\mathrm{pH}$ of the experimental and control cheeses made in this study, suggesting that the addition of blood serum to cheesemilk did not inhibit the cell envelope proteinases of the starter.

The score plot obtained from the PC analysis of the processed peak height data from RP-HPLC chromatograms of the $\mathrm{pH}$ 4.6-soluble fractions of the cheeses is shown in Figure 4. Principal components 1 (PC1) and 2 (PC2) explained $\sim 35 \%$ and $18 \%$, respectively, of the total differences between the peptide profiles of the cheeses and separated the samples on the basis of ripening time and level of blood serum added to milk, respectively. The replicates of control or experimental cheeses were generally close to each other on the score plot, indicating low inter-trial variation. Assuming an arbitrary linkage distance (squared Euclidean distance) cut-off of 12, 


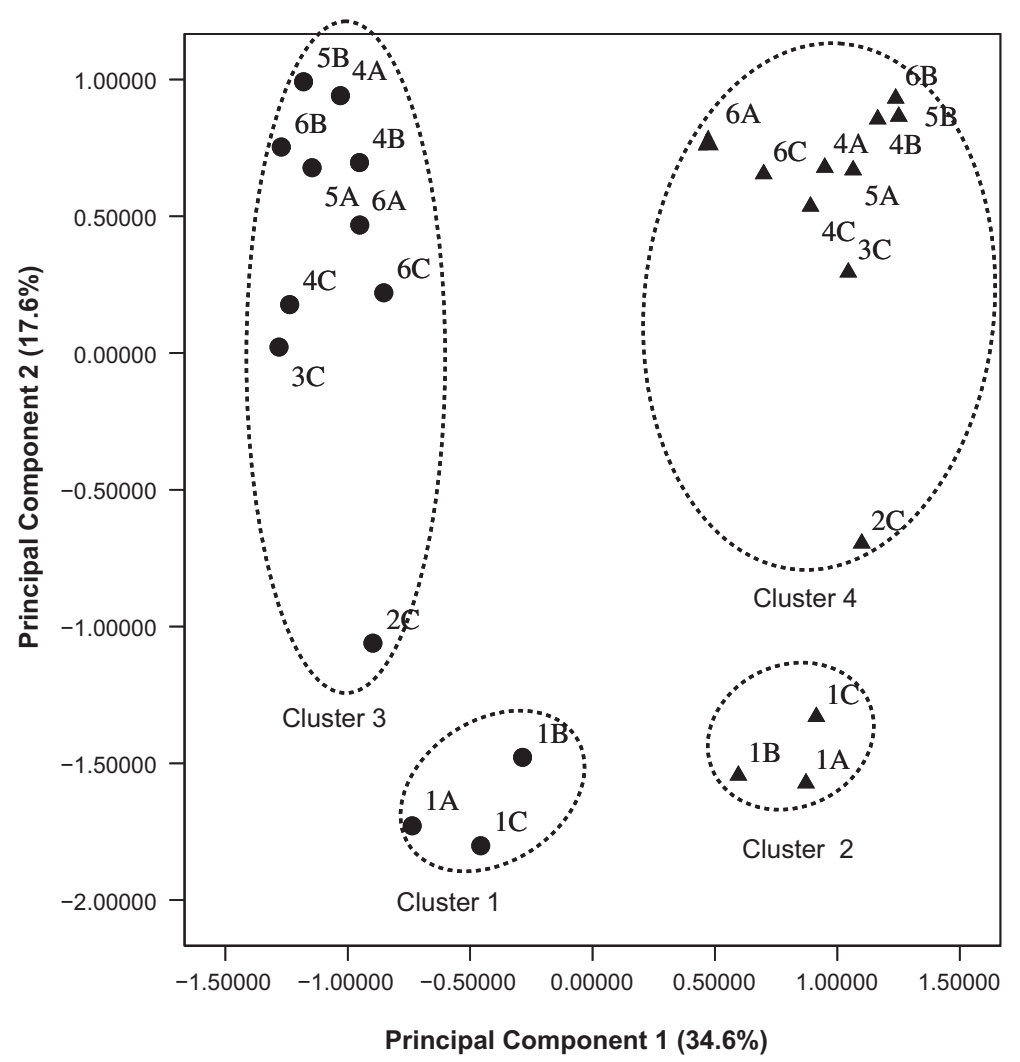

Figure 4. Score plots obtained from the $\mathrm{PC}$ analysis of processed peak height data from RP-HPLC of the $\mathrm{pH}$ 4.6-soluble fractions of Cheddar cheeses of Trials A, B and C made from milk containing 0 (1), 0.1 (2), $0.25(3), 0.4(4), 1(5)$ or 2 (6) \% equine blood serum after $1(\bullet)$ and $180(\mathbf{\Lambda})$ days of ripening. Groupings on the score plot indicate clusters as determined by hierarchical cluster analysis assuming an arbitrary linkage distance (squared Euclidean distance) cut-off of 12 .

hierarchical cluster analysis arranged the cheeses into four clusters on the basis of similarities in their peptide profile. The control cheeses at 1 and 180 days of ripening were grouped into clusters 1 and 2 while the experimental cheeses at 1 and 180 days of ripening were grouped into clusters 3 and 4, respectively (Fig. 4). These results suggest that throughout ripening the peptide profiles of control cheeses were very different from the cheeses made from milk containing blood serum. At both ripening times, the experimental cheeses were clustered together irrespective of the level of serum added, suggesting that equine blood serum effectively inhibits chymosin in cheese at the lowest level used in this study.

The factor loadings on PC1 and PC2 for each retention time class are shown in Figure 5. The retention time classes most highly correlated with PC1 and PC2 were those corresponding to the peptides eluting at $\sim 22$ and 31-43 min, respectively. While 


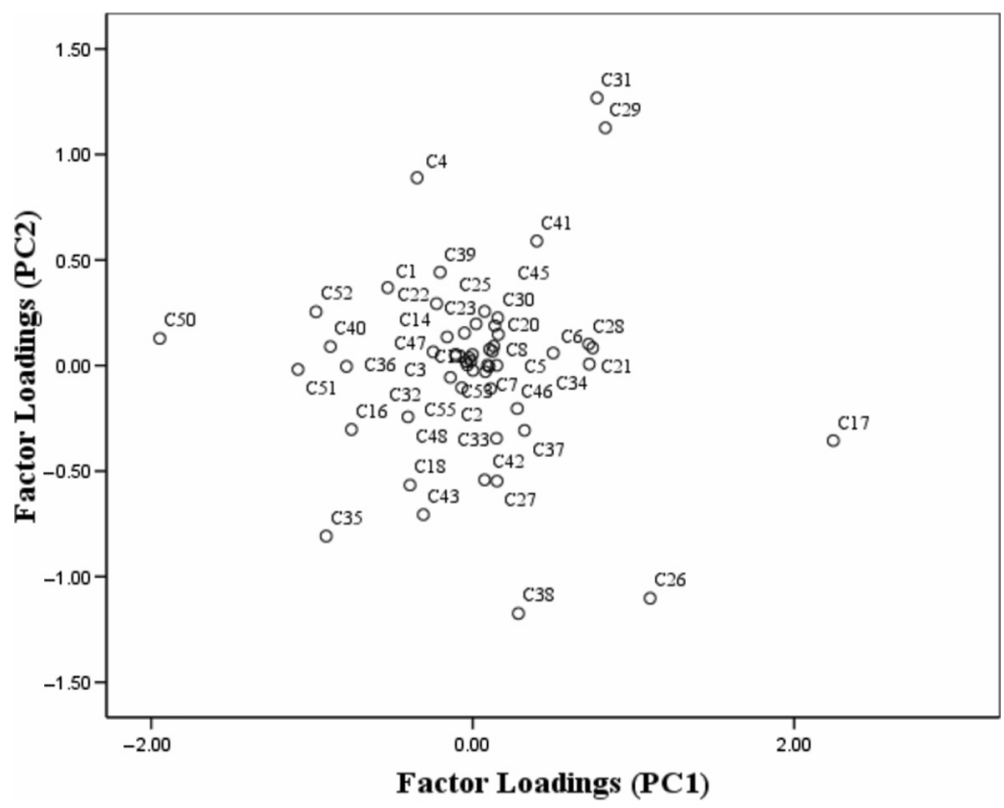

Figure 5. Factor loadings calculated from covariance analysis of each of the retention time classes with PC1 ( $x$-axis) and PC2 ( $y$-axis) from PC analysis of processed peak height data from RP-HPLC of the $\mathrm{pH} 4.6$-soluble fractions of Cheddar cheeses made from milk containing 0 (control), $0.1 \%$, $0.25 \%, 0.4 \%, 1 \%$ or $2 \%$ equine blood serum after 1 and 180 days of ripening.

peptides across the entire profile were responsible for the differences in cheeses, most of the peptides that differentiated the peptide profiles of the cheeses were eluted mainly in the short- to intermediateretention time classes.

\section{CONCLUSIONS}

The levels of equine blood serum used in this study $(0.25-2 \%)$ were very effective at inhibiting the residual chymosin activity during the ripening of Cheddar-type cheeses. The activity of plasmin remained unaffected by the addition of blood serum to cheesemilk. Preparation of "rennet-free" cheeses using the protocol used in this paper would be useful for the study of the separate roles of the coagulant and other proteolytic enzymes in cheese ripening. By separating the first and second phase of rennet coagulation of milk using the principle of coldrenneting, blood serum can be easily incorporated in the traditional protocol for cheesemaking. Since, compared to techniques described in previous studies to produce "rennet-free" cheese, the cheesemaking protocol used here was similar to that for Cheddar, we believe that the technique described in this paper is an easy and effective method for producing cheese curd free from residual coagulant activity.

\section{REFERENCES}

[1] Akaeda H., Mikami M., Miura H., Rennin inhibitor in serum. I. Inhibitor in pig serum on coagulation of milk by rennin, Nippon Nogeikagaku Kaishi 45 (1971) 184-188.

[2] Akaeda H., Miura H., Mikami M., Rennin inhibitor in serum. II. Inhibiting action on 
rennin coagulation by $\alpha_{2}$-macroglobulin, Nippon Nogeikagaku Kaishi 45 (1971) 449-453.

[3] Bansal N., Aggregation of rennet-altered casein micelles at low temperatures and the retention and inactivation of coagulants in cheese curd, Ph.D. Thesis, National University of Ireland, Cork, 2007.

[4] Bansal N., Fox P.F., McSweeney P.L.H., Aggregation of rennet-altered casein micelles at low temperatures, J. Agric. Food Chem. 55 (2007) 3120-3126.

[5] Barrett A.J., Starkey P.M., The interaction of $\alpha_{2}$-macroglobulin with proteinases: characteristics and specificity of the reaction, and a hypothesis concerning its molecular mechanism, Biochem. J. 133 (1973) 709-724.

[6] Creamer L.K., Olson N.F., Rheological evaluation of maturing Cheddar cheese, J. Food Sci. 47 (1982) 631-636.

[7] de Jong L., Protein breakdown in soft cheese and its relation to consistency. 1. Proteolysis and consistency of 'Noorhollandse Meshanger' cheese, Neth. Milk Dairy J. 30 (1976) 242-253.

[8] Effront J., Biochemical Catalysts in Life and Industry, Chapman and Hall Ltd., London, UK, 1917.

[9] Fox P.F., Guinee T.P., Cogan T.M., McSweeney P.L.H., Fundamentals of Cheese Science, Aspen Publishers Inc., Gaithersburg, USA, 2000.

[10] Fox P.F., Law J., McSweeney P.L.H., Wallace J., Biochemistry of cheese ripening, in: Fox P.F. (Ed.), Cheese: Chemistry, Physics and Microbiology, vol. 1, 2nd edn., Chapman and Hall, London, UK, 1993, pp. 389-438.

[11] Fox P.F., McSweeney P.L.H., Rennets: their role in milk coagulation and cheese ripening, in: Law B.A. (Ed.), Microbiology and Biochemistry of Cheese and Fermented Milk, 2nd edn., Blackie Academic and Professional, London, UK, 1997, pp. 1-49.

[12] Hill R.D., Lahav E., Givol D., A renninsensitive bond in $\alpha_{\mathrm{s} 1} \beta$-casein, J. Dairy Res. 41 (1974) 147-153.

[13] Huppertz T., Uniacke T., Kelly A.L., Fox P.F., Inhibition of the proteolytic activity of indigenous plasmin or exogenous chymosin and pepsin in bovine milk by blood serum, Int. Dairy J. 16 (2006) 691-696.

[14] IDF, Determination of the nitrogen content (Kjeldahl method) and calculation of crude protein content, Bulletin 20A, Int. Dairy Fed., Brussels, Belgium, 1986.

[15] Kuchroo C.N., Fox P.F., Soluble nitrogen in Cheddar cheese: comparison of extraction procedures, Milchwissenschaft 37 (1982) 331-335.

[16] Lane C.N., Fox P.F., Johnston D.E., McSweeney P.L.H., Contribution of coagulant to proteolysis and textural changes in Cheddar cheese during ripening, Int. Dairy J. 7 (1997) 453-464.

[17] McLean D.M., Ellis N.J.S., The occurrence of $\alpha_{2}$-macroglobulin in bovine milk and its effect on rennin coagulation of milk, Aus. Dairy Technol. Review Conference 5 (1975) 26.

[18] McSweeney P.L.H., Olson N.F., Fox P.F., Healy A., Højrup P., Proteolytic specificity of chymosin on bovine $\alpha_{\mathrm{s} 1}$-casein, J. Dairy Res. 60 (1993) 401-412.

[19] Mulvihill D.M., Collier T.M., Fox P.F., Manufacture of coagulant-free cheese with piglet gastric proteinases, J. Dairy Sci. 62 (1979) 1567-1569.

[20] O'Keeffe A.M., Fox P.F., Daly C., Denaturation of porcine pepsin during Cheddar cheese manufacture, J. Dairy Res. 44 (1977) 335-343.

[21] O'Keeffe A.M., Fox P.F., Daly C., Proteolysis in Cheddar cheese: role of coagulant and starter bacteria, J. Dairy Res. 45 (1978) 465-477.

[22] O’Mahony J.A., Lucey J.A., McSweeney P.L.H., Chymosin-mediated proteolysis, calcium solubilization, and texture development during the ripening of Cheddar cheese, J. Dairy Sci. 88 (2005) 3101-3114.

[23] O’Mahony J.A., Sousa M.J., McSweeney P.L.H., Proteolysis in miniature Cheddar-type cheeses made using blends of chymosin and Cynara cardunculus proteinases as coagulant, Int. J. Dairy Technol. 56 (2003) 52-58.

[24] Oeda M., Sakaino I., Anti-rennin factor in swine serum. I. Detection of anti-rennin function of some components of swine serum, Nippon Nogeikagaku Kaishi 36 (1962) 764-769.

[25] Piraino P., Parenta E., McSweeney P.L.H., Processing of chromatographic data for chemometric analysis of peptide profiles from cheese extracts: a novel approach, J. Agric. Food Chem. 52 (2004) 6904-6911. 
[26] Rödén H., Uber den Einfluss des Blutserums auf der Gerinnung der Milch mit Lab, Mahly's Jahresbuch 17 (1887) 160-163.

[27] Shakeel-Ur-Rehman, Feeney E.P., McSweeney P.L.H., Fox P.F., Inhibition of residual coagulant in cheese using pepstatin, Int. Dairy J. 8 (1998) 987-992.

[28] Singh L.K., Ganguli N.C., Inhibition of rennin activity by bovine blood serum, Milchwissenschaft 28 (1973) 565-568.

[29] Sousa M.J., Ardö Y., McSweeney P.L.H., Advances in the study of proteolysis in cheese during ripening, Int. Dairy J. 11 (2001) 327-345.

[30] Sousa M.J., McSweeney P.L.H., Studies on the ripening of Cooleeney, an Irish farmhouse Camembert-type cheese, Irish J. Agr. Food Res. 40 (2001) 83-95.

[31] Sugihara H., Nagasawa S., Suzuki T., Studies on $\alpha_{2}$-macroglobulin in bovine plasma. III. Its action on bovine plasma kallikrein, plasmin and thrombin, J. Biochem. 70 (1971) 649-658.

[32] Thomas D.J., Richards A.D., Kay J., Inhibition of aspartic proteinases by $\alpha_{2}$-macroglobulin, Biochem. J. 259 (1989) 905-907.

[33] Tsugo T., Yamauchi K., The inhibition of milk-coagulating enzymes by blood serum, Int. Dairy Congr. Proc. 4 (1953) 641-644.
[34] Upadhyay V.K., McSweeney P.L.H., Magboul A.A.A., Fox P.F., Proteolysis in cheese during ripening, in: Fox P.F., McSweeney P.L.H., Cogan T.M., Guinee T.P. (Eds.), Cheese: Chemistry, Physics and Microbiology, vol. 1, 3rd edn., Elsevier Academic Press, London, UK, 2004, pp. 392-433.

[35] Visser F.M.W., Method for the manufacture of rennet-free cheese, Neth. Milk Dairy J. 30 (1976) 41-54.

[36] Visser F.M.W., Contribution of enzymes from rennet, starter bacteria and milk to proteolysis and flavour development in Gouda cheese. 1. Description of cheese and aseptic cheesemaking techniques, Neth. Milk Dairy 31 (1977) 120-133.

[37] Visser F.M.W., de Groot-Mostert A.E.A., Contribution of enzymes from rennet, starter bacteria, milk to proteolysis, flavour development in Gouda cheese. 4. Protein breakdown gel electrophoretical study, Neth. Milk Dairy J. 31 (1977) 247-264.

[38] Visser S., Proteolytic enzymes and their relation to cheese ripening and flavor: an overview, J. Dairy Sci. 76 (1993) 329-350.

[39] Walstra P., Wouters J.T.M., Geurts T.J., Dairy Science and Technology, 2nd edn., CRC Press, Boca Raton, USA, 2006. 